Arab Univ. J. Agric. Sci., Ain Shams Univ., Cairo, 13(2), 459 - 469, 2005

\title{
DIAGNOSING THE NUTRITIONAL STATUS OF APPLE ORCHARDS AT SOUTH OF JORDAN
}

[29]

\author{
Al-Nasir ${ }^{1}$, F.M. and K.M. Al-Absi ${ }^{1,2}$
}

\begin{abstract}
A test survey was conducted to determine the nutritional status of apple trees grown at four highly productive orchards in south of Jordan. Leaf and soil samples were taken from each orchard, and analyzed for the concentrations of macro- and micronutrients. Soils of Al-Shoubak tend to have high $\mathrm{pH}$, low organic matter and high $\mathrm{CaCO}_{3}$ contents. The results showed that soil concentrations of $\mathrm{N}, \mathrm{K}, \mathrm{Fe}, \mathrm{Mn}$, $\mathrm{Zn}$ and $\mathrm{Cu}$ varied widely among the orchards. No deficiency or hunger signs of $\mathrm{N}, \mathrm{P}$, $\mathrm{K}, \mathrm{Mn}$ and $\mathrm{Zn}$ nutrients were observed at any of the localities since concentrations of leaf nutrients were generally within the sufficient range, indicating adequate levels of fertilization applied to the trees. The leaf analysis has shown that $\mathrm{Cu}$ deficiency is found in some apple orchards. Soils and leaf nutrient levels were generally not well correlated with one another. The only highly significant correlation was between soil $\mathrm{P}$ and leaf $\mathrm{N}$. However, positive relations were observed among leaf $\mathrm{P}$ and $\mathrm{Mn}, \mathrm{Fe}$ and $\mathrm{Mn}, \mathrm{Fe}$ and $\mathrm{Zn}$, and $\mathrm{Mn}$ and $\mathrm{Zn}$ contents.
\end{abstract}

Key words: Al-Shoubak, Correlation coefficient, Fertilizer, Leaf analysis, Macroand micronutrients, Sufficient range

\section{INTRODUCTION}

Apple (Malus domestica) is considered one of the most widely distributed fruit trees in Jordan. The area planted to this crop increased rapidly during the last two decades and reached about 3.9 thousand ha in 2003. This represents $4.5 \%$ of the total area planted with fruit trees. The majority of the Jordanian apple area is located in Al-Shoubak. Despite the significance of the local apple industry to the economy of the Governorate and the country, very little work had been conducted to evaluate nutritional status of apple trees in Jordan.

The nutritional status can be determined by observation of tree performance, leaf analysis and soil analysis. Soil analysis is of a value in determining the level of immediately available nutrients in the soil. Interpretation of soil analysis allows for assessing fertilizer needs, but it is poorly correlated with tree nutrient uptake to ensure optimal growth and productivity of the plants. So, in

1- Dept. Plant Production, Faculty of Agriculture, Mu'tah University, Jordan

2- E. mail: absikhal@yahoo.com 
many cases, soil analysis is not a satisfactory guide for making fertilizers recommendations. Leaf analysis, on the other hand, is based on the comparison of the nutrient concentration with critical reference values. The potential role of leaf analysis in fertilizer use includes evaluation of the rates of nutrient inputs needed; checking on nutrient deficiencies, interaction or antagonisms; and determination of whether the fertilizers applied are being utilized by the plants. The nutrient concentration at which the maximum relative yield, is the critical nutrient concentration (CNC). There is a transition zone in which the concentration changes from deficient to sufficient. Much research has been done to establish the CNC and transition zones for many crops (Rana et al 1984, Haynes 1990). The advantage of plant parts analysis is that it indicates how much nutrients the crop was getting from the fertilizers applied at the time the sample was taken; while soil analysis can only show what the plant might get. The interpretation of leaf analysis results for the different samples should take into account: varietal (Tagliavini et al 1992) as well as rootstock differences (Ershadi and Talaie 2001, Slowinski and Sadowski 2001, Wojcik 2002) and fertilization (Neilsen et al 2001, Raese 1996, Zydlik and Pacholak 2001). Seasonal trends in plant analysis results have been reported (Drossopoulos et al 1996). The seasonal trend has been the most consistent for $\mathrm{N}, \mathrm{P}, \mathrm{K}, \mathrm{Ca}, \mathrm{Mg}, \mathrm{Mn}$ and $\mathrm{B}$ (Tagliavini et al 1992).

In addition to leaf analysis, flower analysis was also, used as an early method of diagnosis the nutritional status of pear and peach (Sanz and Montanes 1995), and orange (Pestana et al 2001) trees, in order to give the growers the chance to correct nutrient deficiencies and prevent yield impairment in the same year.

Recently, much interest has been developed in ideal utilization of the fertilizers with an optimum rate. Accordingly, the objective of this survey was to determine the current status of leaf analysis and soil testing in various apple orchards located at Al-Shoubak area in south of Jordan and to investigate the relationships among some nutrients in order to develop a guideline for the use of leaf and soil analysis as basis for fertilizer recommendation and optimization of apple growth and production of high quality fruits.

\section{MATERIAL AND METHODS}

\section{Field site}

This study was conducted on mature 'Golden Delecious', 'Granny Smith' and 'Royal Gala' apple trees grafted on M9 rootstock, without symptoms of nutrient deficiency, and spaced $3 \times 1.5 \mathrm{~m}$, in four highly productive orchards; namely: Hashlamoun (100ha), Tarawneh (50ha), Zanouneh (3.5ha), and Abualhaj (2500ha), located at Al-Shoubak area during the 2001 growing season. AlShoubak is one of the most important locations of growing apples in the Mediterranean region. It is located $250 \mathrm{Km}$ to the south of the capital Amman, in which adverse climatic conditions such as cold winter, late spring frost and very low mean annual rainfall (average less than $250 \mathrm{~mm}$ ) are dominated. Approximate mean daily maximum and minimum temperatures are 5 and $12^{\circ} \mathrm{C}$ in winter, and 18 and $32^{\circ} \mathrm{C}$ in summer, respectively. The main chemical properties of the soils of the four experimental orchards are shown in Table (1). 
Table 1. Selected chemical properties of the soils of the four experimental orchards

\begin{tabular}{|lcccc|}
\hline \multirow{2}{*}{\multicolumn{1}{c}{ Analysis }} & \multicolumn{4}{c|}{ Orchard name } \\
\cline { 2 - 5 } & $\begin{array}{c}\text { Hashlamoun } \\
(\mathrm{H})\end{array}$ & $\begin{array}{c}\text { Tarawneh } \\
(\mathrm{T})\end{array}$ & $\begin{array}{c}\text { Zanouneh } \\
(\mathrm{Z})\end{array}$ & $\begin{array}{c}\text { Abualhaj } \\
(\mathrm{A})\end{array}$ \\
\hline PH (in water, 1:2.5) & $7.93 \mathrm{~b}$ & $7.99 \mathrm{ab}$ & $8.09 \mathrm{ab}$ & $8.14 \mathrm{a}$ \\
Total CaCO 3 & $24.1 \mathrm{a}$ & $23.65 \mathrm{a}$ & $25.85 \mathrm{a}$ & $24.90 \mathrm{a}$ \\
Organic matter(\%) & $1.75 \mathrm{ab}$ & $2.15 \mathrm{a}$ & $1.97 \mathrm{ab}$ & $1.56 \mathrm{~b}$ \\
E.C. $(\mathrm{dS} / \mathrm{m})$ & $0.96 \mathrm{a}$ & $0.78 \mathrm{a}$ & $0.97 \mathrm{a}$ & $0.63 \mathrm{a}$ \\
Total N $(\mathrm{ppm})$ & $957.4 \mathrm{~b}$ & $1198.7 \mathrm{a}$ & $912.5 \mathrm{~b}$ & $634.2 \mathrm{c}$ \\
Available P $(\mathrm{ppm})$ & $582.0 \mathrm{a}$ & $545.9 \mathrm{a}$ & $582.0 \mathrm{a}$ & $509.4 \mathrm{a}$ \\
Available K(ppm) & $92.5 \mathrm{~b}$ & $129.37 \mathrm{a}$ & $118.45 \mathrm{a}$ & $57.25 \mathrm{c}$ \\
Extraxtable Fe $(\mathrm{ppm})$ & $16.82 \mathrm{~b}$ & $27.67 \mathrm{a}$ & $11.07 \mathrm{bc}$ & $7.15 \mathrm{c}$ \\
Extraxtable $\mathrm{Mn}(\mathrm{ppm})$ & $98.38 \mathrm{~b}$ & $130.4 \mathrm{a}$ & $76.5 \mathrm{~b}$ & $76.9 \mathrm{~b}$ \\
Extraxtable $\mathrm{Zn}(\mathrm{ppm})$ & $1.91 \mathrm{~b}$ & $2.97 \mathrm{a}$ & $2.84 \mathrm{a}$ & $0.57 \mathrm{c}$ \\
Extraxtable Cu $(\mathrm{ppm})$ & $4.89 \mathrm{a}$ & $3.34 \mathrm{~b}$ & $4.63 \mathrm{a}$ & $2.71 \mathrm{~b}$ \\
\hline
\end{tabular}

Means within rows followed by the same letter are not significantly different at $\mathrm{P}=0.05$ (DMRT).

\section{Experimental procedure and meas- urements}

Because the bulk of the M9 root systems is spread in the soil surface layer, ninety-six surface soil samples (0 to 30 $\mathrm{cm})$ were collected from those orchards (24 sample from each orchard) in June 2001. Each sample was collected from three trees. The samples were kept in polyethylene bags and brought to the laboratory for chemical analysis. Therefore, they were air-dried and then passed through a $2 \mathrm{~mm}$ sieve. The soil texture was determined using the Bouyoucus hydrometer method based on the particle settling in a dispersed solution were determined according to the standard procedures of the United States Salinity Labor- atory Staff (USSL, 1954). Organic matter content of the different soil samples was measured using $\mathrm{H}_{2} \mathrm{O}_{2}$ as an oxidizing agent. Calcium carbonate $\left(\mathrm{CaCO}_{3} \%\right)$ content was measured by Calcimeter method (USSL, 1954). The $\mathrm{pH}$ and electrical conductivity were also measured. Soil nitrogen $(\mathrm{N})$, phosphorus $(\mathrm{P})$, potassium $(\mathrm{K})$, iron $(\mathrm{Fe})$, manganese $(\mathrm{Mn})$, zinc $(\mathrm{Zn})$ and cupper $(\mathrm{Cu})$ were determined by flame photometer as described by Tandon (1995).

In order to determine the leaf mineral composition, representative 96 samples of two leaves usually 4th-5th mature leaves from randomly distributed shoots that were collected randomly around the selected trees 4 weeks after full bloom in July 2001 from the four selected or- 
chards. Twenty four samples were collected from each orchard and each is a composite of the four mentioned cultivars. They were washed with distilled water and oven dried at $70^{\circ} \mathrm{C}$ till constant weight was obtained. The samples were ground and digested with nitric acid (ElHassan et al 2002). From these solutions, the subsequent analyses were performed. Nitrogen $(\mathrm{N})$ was determined by a semimicro-Kjeldahl method (Bermner and Mulvaney, 1982). Phosphorus (P) was measured by atomic emission spectrophotometer (Tandon, 1995). Potassium (K) was determined by flame photometer as described by Tandon, (1995). Copper $(\mathrm{Cu})$, iron $(\mathrm{Fe})$, manganese $(\mathrm{Mn})$ and zinc ( $\mathrm{Zn})$ were determined by an atomic absorption spectrophotometer.

\section{Statistical design and analysis}

The experimental design was completely randomized design. The data were subjected to analysis according to Snedecor and Cochran (1980). The analysis of variance (ANOVA) was used to determine significant differences. Means were compared by using the method of Duncan's Multiple Range Test (DMRT) at 5\% level. In addition, the correlation coefficients among the different leaf nutrient concentrations and the relationship between leaf and soil mineral contents have been investigated.

\section{RESULTS}

The results of selected chemical analysis of the soil samples collected from Hashlamoun (H), Tarawneh (T), Zanouneh (Z) and Abualhaj (A) orchards are given in Table (1). Soil analyses carried out in the studied orchards have shown that there were no considerable variations in E.C and $\mathrm{CaCO}_{3}$ values. It is clear that soils of tested orchards tend to have high $\mathrm{pH}$, and low organic matter content. The $\mathrm{pH}$ of the soils varied between 7.93 and 8.14. The highest value of $\mathrm{pH}$ was found at (A), while the lowest one was found at $(\mathrm{H})$. Soil analysis data show that organic matter content of $(\mathrm{T})$ orchard was significantly higher than that of (A). Total soil $\mathrm{N}$ concentration at (T) was higher than in either of the other orchard sites. Similar differences were found among the orchards for soil $\mathrm{Fe}$ content. The lowest soil $\mathrm{N}$ and $\mathrm{Fe}$ were found at $(\mathrm{A})$ orchard. There were few and inconsiderable variations in available soil $\mathrm{P}$ concentration among the studied apple orchards. Soil of (T) orchard had lower P than $(\mathrm{H})$ and $(\mathrm{Z})$ orchards and higher than (A) orchard. The levels of available soil $\mathrm{K}$ showed significant variation, with concentrations of $129.37,118.45,92.50$ and $57.25 \mathrm{ppm}$ at $(\mathrm{T}),(\mathrm{Z}),(\mathrm{H})$ and $(\mathrm{A})$ orchards, respectively. Concerning Mn content, soil of $(\mathrm{T})$ had higher concentration than the other orchards. Soils of $(\mathrm{Z})$ and (A) had the lowest values (76.5, 76.9 ppm, respectively). There was a wide range of values for extractable soil $\mathrm{Zn}$ content. The mean concentration was found to be in the order $(\mathrm{T})$ and $(\mathrm{Z})>(\mathrm{H})$ $>$ (A). A significant difference in soil $\mathrm{Cu}$ content was found at the studied orchards. Soils of $(\mathrm{H})$ and $(\mathrm{Z})$ orchards had higher concentrations than those of $(\mathrm{T})$ and $(\mathrm{A})$ orchards.

With regard to apple leaf composition, the reference values used for interpreting the results of apple leaf analysis, which were established by Ohio Plant Analysis Laboratory, Ohio, USA, as recommended by Rana $\boldsymbol{e t}$ al (1984) are listed in Table (2). The mean values with standard deviations, minimum and maximum values for 
leaf nutrient concentration are presented in Table (3). The $\mathrm{N}$ content in leaf samples of the four studied orchards varied from 0.91 to $2.75 \%$ with a mean of $2.05 \%$. The survey results indicate that $\mathrm{N}$ concentrations at all orchards were within the optimum range. Furthermore, there were no significant differences in leaf $\mathrm{N}$ content among apple trees of the studied orchards (Table, 4). In addition, Leaf $\mathrm{P}$, $\mathrm{K}, \mathrm{Mn}, \mathrm{Fe}$ and $\mathrm{Zn}$ nutrient concentrations (Tables 3 and 4) were above the deficient levels (Table, 2). Except for $(Z)$ orchard, the leaf samples of $(\mathrm{H}),(\mathrm{T})$ and $(\mathrm{A})$ orchards demonstrated $\mathrm{Cu}$ deficiency (Table 3 and 4). These results indicate that all trees are capable of absorbing the elements in sufficient quantities to sustain adequate growth and production. However, growers of the studied orchards should constantly monitor their trees for $\mathrm{Cu}$ content in order to correct the deficiency with foliar or soil applications or combination of the two. The only possible incipient luxury identified was the high leaf $\mathrm{Zn}$ concentration $(62.25 \mathrm{ppm})$ found in $(Z)$ orchard (Table 4). The leaf Fe, Mn, Zn and $\mathrm{Cu}$ contents at $(\mathrm{Z})$ orchard were considerably higher than those of the other orchards (Table 4). The leaf concentration of $\mathrm{Fe}$ at $(\mathrm{Z})$ orchard was two times higher than at $(\mathrm{H})$ and $(\mathrm{A})$ orchards. On the contrary, the lowest leaf Fe, Mn and $\mathrm{Cu}$ contents were found at $(\mathrm{H})$ orchard, and the lowest content of leaf $\mathrm{Zn}$ was found at $(\mathrm{T})$ orchard.

Table (5) shows the correlation coefficients between soil and leaf nutrient contents. For most nutrients, no significant correlations were found among soil and leaf nutrient contents. The only highly significant correlation (0.355) was found between soil $\mathrm{P}$ and leaf $\mathrm{N}$ levels. The correlation coefficients among leaf nutrient concentrations are shown in Table (6). The linear analysis indicated that there was no interrelations among most of leaf nutrients. The correlations were recorded only between P and Mn (0.213), Fe and $\mathrm{Mn}$ (0.323), Fe and $\mathrm{Zn}(0.572)$ and $\mathrm{Mn}$ and $\mathrm{Zn}(0.227)$.

\section{DISCUSSION}

The soil analysis of the studied orchards at Al-Shoubak area indicated that these soils are calcareous with extremely low organic matter and high $\mathrm{pH}$ value content. There were considerable variations among the orchards in $\mathrm{pH}$ value and organic matter content. In the case of soil $\mathrm{P}$ concentration, no clear variation was found in the orchards. However, significant differences were observed in soil $\mathrm{N}$, $\mathrm{K}, \mathrm{Fe}, \mathrm{Mn}, \mathrm{Cu}$ and $\mathrm{Zn}$ contents among the orchards. The soil of $(\mathrm{T})$ orchard had higher soil N, K, Fe, Mn and Zn contents than the others. On the other hand, the lowest values of the previous nutrients, except Mn, were found at (A) orchard. These results may be attributed to the differences in organic matter content, soil texture, cultural practices and fertilizer management methods followed by the different growers. The mineral contents of soils of the current study are considered very high if compared with soils of Jordan Valley and other regions of the country (Hattar and Khattari, 1995) and most of them are above the critical level growth of most plants.

The chemical analysis of plant leaves for diagnostic purposes is based on the casual relationship exist between plant growth and their mineral content (Kenworthy, 1973 and Marschner, 1995). As already noted, concentrations of leaf N, P, $\mathrm{K}, \mathrm{Mn}$ and $\mathrm{Zn}$ were generally within the 
Table 2. Standard values and ranges used for diagnostic purposes on apple trees*

\begin{tabular}{|lcccc|}
\hline Nutrient & Deficient & Low & Optimum & High \\
\hline $\mathrm{N},(\%)$ & $<1.5$ & $1.5-1.8$ & $1.9-2.4$ & $>2.5$ \\
$\mathrm{P},(\%)$ & $<0.14$ & $0.14-0.18$ & $0.19-0.28$ & $>0.30$ \\
$\mathrm{~K},(\%)$ & $<1.0$ & $1.0-1.2$ & $1.3-1.8$ & $>1.9$ \\
$\mathrm{Ca},(\%)$ & $<1.0$ & $1.0-1.2$ & $1.3-1.7$ & $>1.8$ \\
$\mathrm{Mg},(\%)$ & $<0.2$ & $0.20-0.24$ & $0.25-0.36$ & $>0.37$ \\
$\mathrm{Fe}, \mathrm{ppm}$ & $<30$ & $30-35$ & $36-150$ & $>150$ \\
$\mathrm{Mn}, \mathrm{ppm}$ & $<25$ & $25-30$ & $31-150$ & $>150$ \\
$\mathrm{Zn}, \mathrm{ppm}$ & $<15$ & $15-20$ & $21-50$ & $>50$ \\
$\mathrm{Cu}, \mathrm{ppm}$ & $<5$ & $5-10$ & $11-20$ & $>20$ \\
\hline
\end{tabular}

*Rana R.S.; R.B. Sharma and K.C. Azad (1984). Nutritional status of apple orchards in Hinachal Pradesh. Indian J. Hort. 41: 244-250.

Table 3. Mean and standard deviation, minimum and maximum leaf nutrient concentrations of apple trees at the four orchard sites.

\begin{tabular}{|lccc|}
\hline Nutrient & Mean $\pm \mathrm{SD}$ & Minimum & Maximum \\
\hline $\mathrm{N},(\%)$ & $2.05 \pm 0.42$ & 0.91 & 2.75 \\
$\mathrm{P},(\%)$ & $0.19 \pm 0.09$ & 0.030 & 0.45 \\
$\mathrm{~K},(\%)$ & $1.41 \pm 0.58$ & 0.66 & 5.80 \\
$\mathrm{Fe}, \mathrm{ppm}$ & $233.75 \pm 107.87$ & 95.50 & 588.00 \\
$\mathrm{Mn}, \mathrm{ppm}$ & $113.60 \pm 42.15$ & 41.00 & 238.00 \\
$\mathrm{Zn}, \mathrm{ppm}$ & $38.01 \pm 27.40$ & 11.00 & 189.00 \\
$\mathrm{Cu}, \mathrm{ppm}$ & $11.10 \pm 9.17$ & 3.00 & 65.00 \\
\hline
\end{tabular}


Table 4. Average leaf $\mathrm{N}, \mathrm{P}, \mathrm{K}, \mathrm{Fe}, \mathrm{Mn}, \mathrm{Zn}$ and $\mathrm{Cu}$ contents for apple trees grown at four orchards at south of Jordan

\begin{tabular}{|lcccc|}
\hline & \multicolumn{4}{c|}{ Orchard Name } \\
\cline { 2 - 5 } Analysis & $\begin{array}{c}\text { Hashlamoun } \\
(\mathrm{H})\end{array}$ & $\begin{array}{c}\text { Tarawneh } \\
(\mathrm{T})\end{array}$ & $\begin{array}{c}\text { Zanouneh } \\
(\mathrm{Z})\end{array}$ & $\begin{array}{c}\text { Abualhaj } \\
(\mathrm{A})\end{array}$ \\
\hline $\mathrm{N}(\%)$ & $2.17 \mathrm{a}$ & $2.07 \mathrm{a}$ & $1.97 \mathrm{a}$ & $2.07 \mathrm{a}$ \\
$\mathrm{P}(\%)$ & $0.20 \mathrm{a}$ & $0.21 \mathrm{a}$ & $0.22 \mathrm{a}$ & $0.17 \mathrm{a}$ \\
$\mathrm{K}(\%)$ & $1.28 \mathrm{a}$ & $1.29 \mathrm{a}$ & $1.41 \mathrm{a}$ & $1.39 \mathrm{a}$ \\
$\mathrm{Fe}(\mathrm{ppm})$ & $170.20 \mathrm{bc}$ & $206.75 \mathrm{~b}$ & $364.08 \mathrm{a}$ & $182.75 \mathrm{~b}$ \\
$\mathrm{Mn}(\mathrm{ppm})$ & $82.65 \mathrm{c}$ & $126.13 \mathrm{ab}$ & $137.13 \mathrm{a}$ & $112.65 \mathrm{~b}$ \\
$\mathrm{Zn}(\mathrm{ppm})$ & $28.93 \mathrm{~b}$ & $26.83 \mathrm{~b}$ & $62.25 \mathrm{a}$ & $33.30 \mathrm{~b}$ \\
$\mathrm{Cu}(\mathrm{ppm})$ & $8.87 \mathrm{~b}$ & $8.95 \mathrm{~b}$ & $16.33 \mathrm{a}$ & $9.53 \mathrm{~b}$ \\
\hline
\end{tabular}

Means within rows followed by the same letter are not significantly different at $\mathrm{P}=0.05$ (DMRT).

Table 5. Correlation coefficients between soil and leaf nutrient concentrations collected from the four-apple orchards at Al-Shoubak area

\begin{tabular}{|lccccccc|}
\hline \multirow{2}{*}{$\begin{array}{c}\text { Soil } \\
\text { content }\end{array}$} & $\mathrm{N}$ & $\mathrm{P}$ & $\mathrm{K}$ & $\mathrm{Fe}$ & $\mathrm{Mn}$ & $\mathrm{Zn}$ & $\mathrm{Cu}$ \\
\cline { 2 - 8 } $\mathrm{N}$ & 0.068 & -0.060 & -0.022 & -0.110 & 0.021 & -0.111 & -0.004 \\
$\mathrm{P}$ & $0.355^{* *}$ & 0.078 & -0.157 & 0.057 & -0.027 & 0.065 & -0.10 \\
$\mathrm{~K}$ & 0.177 & -0.003 & -0.098 & -0.012 & -0.034 & -0.065 & -0.001 \\
$\mathrm{Fe}$ & 0.180 & 0.156 & -0.021 & -0.005 & -0.030 & 0.049 & 0.009 \\
$\mathrm{Mn}$ & 0.139 & 0.144 & 0.021 & 0.109 & -0.044 & -0.008 & 0.027 \\
$\mathrm{Zn}$ & 0.191 & -0.007 & -0.206 & -0.206 & -0.043 & -0.053 & -0.012 \\
$\mathrm{Cu}$ & 0.074 & -0.136 & -0.049 & -0.056 & -0.132 & -0.100 & 0.094 \\
\hline
\end{tabular}

**Significant at level of $1 \%$ probability. 
Table 6. Correlation coefficients between macro- and micronutrients concentrations in apple tree leaves collected from the four-apple orchards at AlShoubak area.

\begin{tabular}{|lcccccc|}
\hline Nutrient & $\mathrm{N}$ & $\mathrm{P}$ & $\mathrm{K}$ & $\mathrm{Fe}$ & $\mathrm{Mn}$ & $\mathrm{Zn}$ \\
\hline $\mathrm{P}$ & 0.184 & & & & & \\
$\mathrm{~K}$ & -0.178 & 0.031 & & & & \\
$\mathrm{Fe}$ & 0.020 & 0.095 & 0.099 & & & \\
$\mathrm{Mn}$ & 0.033 & $0.213^{*}$ & -.0051 & $0.323^{* *}$ & & \\
$\mathrm{Zn}$ & 0.130 & 0.157 & 0.076 & $0.572^{* *}$ & $0.227^{*}$ & \\
$\mathrm{Cu}$ & 0.162 & 0.090 & 0.022 & 0.118 & 0.176 & 0.099 \\
\hline
\end{tabular}

$*, * *$ Significant at level of $5 \%$ and $1 \%$ probability, respectively

sufficiency range (Tables, 2 and 3), indicating adequate levels of fertilization applied to the trees. No deficiency or hunger signs of these nutrients were observed at any orchard. Thus, a continuing moderate supply of the previous elements is essential for sustained fruit production. The contents of leaf macronutriens (Tables, 3 and 4) in the study area were generally similar to those obtained by Haynes, (1990), while miconutrients levels, except $\mathrm{Zn}$, were higher. However, the results have shown that $\mathrm{Cu}$ deficiency is found in most apple orchards. The deficiency of a micronutrient or more, in apple orchards, was reported by Cline, (1990) and Slowinski \& Sadowski (2001). Furthermore, Fe in leaves of all orchards was generally in the higher limit range, indicating an oversupply of $\mathrm{Fe}$ fertilizers to the vast majority of the four orchards and that the fertilizer additions of these nutrients could be substantially reduced. In addition, the excessive use of the chemical fertilizers can dramatically influence the balance of nutritional elements in plants. The leaf Fe levels found in this study are very high in comparison with values observed in India (Rana $\boldsymbol{e t}$ al 1984) and New Zealand (Haynes, 1990). Awasthi and Kaith (1990), indicating that crop load largely determines the nutrient uptake of the trees and could be used as a guide for the fertilization of apple orchards. It is of prime importance to mention that flower buds and flowers were successfuly used to predict the nutritional status and fertilization requirement of apple trees (Wojcik, 2002).

In the current study, the complexity of the soil plant relationship in apple trees and influence of cultural practices and environmental conditions on nutrient uptake may explain the lack of close relationship among soil and leaf nutrient contents, except between soil $\mathrm{P}$ and leaf $\mathrm{N}$ (Table, 3) Thus, contents of soil nutrients are not often a good reflection of contents of leaf nutrients. However, the high concentrations of most nutrients in leaves 
reflect the high content of them in the soil. The absence of clear correlations among leaf and soil levels was reported by other workers (Basso et al 1990, Haynes 1990). Concerning correlations among leaf nutrient levels, significant correlation coefficients were obtained between $\mathrm{P}$ and $\mathrm{Mn}, \mathrm{Fe}$ and $\mathrm{Mn}, \mathrm{Fe}$ and $\mathrm{Zn}$, and $\mathrm{Mn}$ and $\mathrm{Zn}$. Similarly, high significant correlations were found between $\mathrm{Fe}$ and $\mathrm{Mn}$ in coffee-tree leaves and flowers (Martinez et al 2003). However, the values of coefficients were higher than those determined in the present study.

\section{REFERENCES}

Awasthi, R.P. and N.S. Kaith (1990). The effect of crop load in assessing the nutrient requirements of apple trees. Acta Hort. 274: 231- 236.

Basso C.; F.W. Wilms and H. Stuker (1990). Soil-plant-fruit nutritional relationship in apple orchards in southern Barazil. Acta Hort. 274: 33-42.

Bermner, J.M. and C.S. Mulvaney (1982). Nitrogen-total. Cited from Page, A.L. Methods of Soil Analysis. pp. 595642. Amer. Soc. Agr., Madison, WI.

Cline, R.A. (1990). Thirty years of diagnosing nutritional status of deciduous orchards and vineyards by leaf analysis in Ontario, Canada. Acta Hort. 274: 107112.

Drossopoulos, J.B.; G.G. Kouchaji and D.L. Bouranis (1996). Seasonal dynamics of mineral nutrients by walnut tree fruits. J. Plant Nutr. 19: 435-455.

El-Hassan T.; H. Al-Omari; A. Jiries and F. Al-Naser (2002). Cupress tree (Cupressus sempervirens L.) bark as an indicator for heavy metal polution in the atmosphere of Amman city, Jordan. Environ. Intrern. 28: 513 - 519.
Ershadi, A. and A. Talaie (2001). The effect of clonal rootstocks on leaf mineral composition of several apple cultivars. Acta Hort. 564: 317-320.

Hattar, B. and S.K. Khattari (1995). Relationships between micronutrients level in soil and plant with soil properties of the Jordan Valley region. Dirasat 22: 51-67.

Haynes, R.J. (1990). Nutrient status of apple orchards in Canterbury, New Zelaand. 1. Levels in soil, leaves and fruit and the prevalence of storage disorders. Commun. in Soil Sci. Plant Analysis 21: 903-920.

Kenworthy, A.L. (1973). Leaf Analysis as an Aid in Fertilizing Orchards. Cited from Walsh L.M. and J.D. Beaton (eds). Soil Testing and Plant Analysis. pp. 152-167. Soil Science. Society of America, Inc. USA.

Marschner, H. (1995). Mineral Nutrition of Higher Plants, $2^{\text {nd }}$ Ed., pp. 463475. Academic Press, New York.

Martinez, H.E.; R.B. Souza; J.A. Bayona; V.H. Venegas and M. Sanz. (2003). Coffee-tree floral analysis as a mean of nutritional diagnosis. J. Plant Nutr. 26: 1467- 1482.

Neilsen D.; P. Millard; G. Neilsen and E. Hogue (2001). Nitrogen uptake, efficiency of use, and partitioning for growth in young apple trees. J. Amer. Soc. Hort. Sci. 126:144-150.

Pestana, M.; P. Correia; A. Varennes; J. Abadia and E. Faria (2001). The use of floral analysis to diagnose the nutritional status of orange trees. J. Plant Nutr. 24: 1913-1923.

Raese, J.T. (1996). Calcium nutrition affects cold hardiness, yield, and fruit disorders of apple and pear trees. J. Plant Nutr. 19: 1131-1155. 
Rana, R.S.; R.B. Sharma and K.C. Azad (1984). Nutritional status of apple orchards in Hinachal Pradesh. Indian $\boldsymbol{J}$. Hort. 41: 244-250.

Sanz M. and L. Montanes (1995). Floral Analysis: A Novel Approach for The Prognosis of Iron Deficiency in Pear (Pyrus communis) and Peach (Prunus persica L. Batsch), Cited from Abadia, J., Iron Nutrition in Soils and Plants. pp. 371374. Kluwer Academic Publishers: Dordrecht, The Netherlands.

Slowinski, A. and A. Sadowski (2001). Mineral element content in leaves of different apple rootstocks and of the Elise scion cultivar on the same rootstocks. Acta Hort. 564: 309-316.

Snedecor, G.W. and W.G. Cochran (1980). Statistical Methods. $7^{\text {th }}$ Ed., Iowa State Univ. Press. Ames, Iowa. USA.

Tagliavini, M.; D. Scudellari; B. Marangoni; V. Bastianel; F. Franzin and M. Zamborlini (1992). Leaf mineral composition of apple tree : Sampling date and effects of cultivar and rootstock. $J$. Plant Nutr. 15: 609-615.
Tandon H.L. (1995). Methods of Analysis of Soils, Plants, Waters and Fertilizers. p. 82. Fertilizer Development and Consultation Organization. New Delhi.

United States Salinity Laboratory Staff (1954) Diagnosis and Improvement of Saline and Alkali Soils. USDA Handbook, Vol. 60, p. 24. Washington, DC.

Velemis D.; D. Almaliotis; S. Bladenopoulou and N. Karapetsas (1999). Leaf nutrient levels of apple orchards (cv. Starkrimson) in relation to crop yield. Adv. Hort. Sci. 13:147-150.

Wojcik, P. (2002). Boron analysis in tissue before apple tree bloom can be used to assess boron nutritional status. $\boldsymbol{J}$. Plant Nut. 25:1011-1020.

Zamborlini, (1992). Leaf mineral composition of apple tree: Sampling date and effects of cultivar and rootstock. J. Plant Nutr. 15: 605-619.

Zydlik Z. and E. Pacholak (2001). Fertigation effects on the concentration of mineral components in the soil and leaves, and the yield and quality of fruits in two apple-tree cultivars. Acta Hort. 564: 457-463. 
بحلة اتحاد الجحامعات العربية للدراسات والبحوث الزراعية ، جامعة عين شمس ، القاهرة ، 13(2) ، 459 - 469 ، 2005

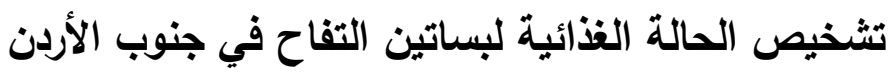

[29]

$$
\begin{aligned}
& \text { فرح موسى الناصر } 1 \text { - خالا موسيى العبسي } 1 \\
& \text { 1- فسم الإنتاج النباتي - كلية الزراعة - جامعة مؤتة - الكرك - الأردن }
\end{aligned}
$$

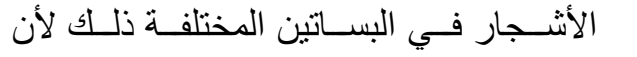

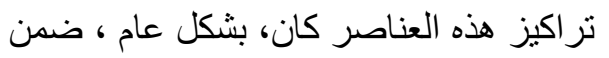

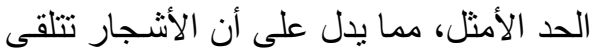
مستويات كافية من الأسمدة.

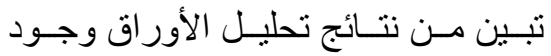

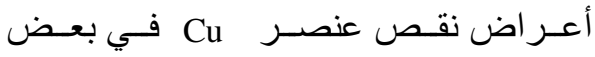

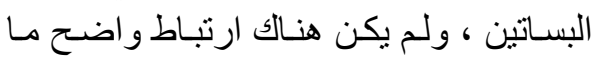
بين مستويات العناصر الغذائيسة في الأوراق و الترب. وقد كان الارتبـاط المعنوى مـا بين محتوى التربـة مـن P ومحتوى الأوراق مـن الأن

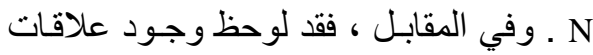
إيجابية و اضحسة في محتـوى الأوراق ما بين

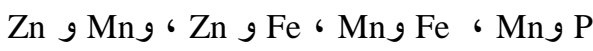

تـم إجـر اء هـذا الفحـص لتحديــد الحالـة

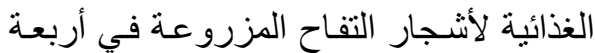

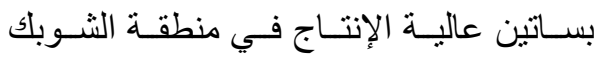
جنوب الأردن.تم جمع عينـات أوراق و نبـات الإن من كل بستان، وتم تحليلها من حيث بعض فض

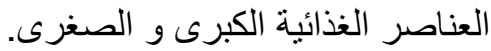
تبين من النتائج أن ترب البساتين الأردنية

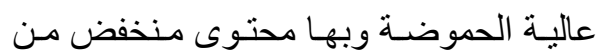
المـادة العضـوية ومحتـوى عـال مـن الجيـر. N, K, Fe, كـا أظهـرت النتائج أن تراكيز م و Mn, Zn ما بين البساتين المختلفة.

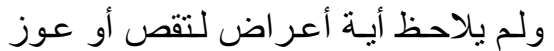
العناصـر N, P, K, Mn و في أوراق

تحكيم: أ.د ابر اهيم شوقى السيد 